https://www.amerabra.org; https://fspu.uitm.edu.my/cebs; https://www.emasemasresources.com/ $5^{\text {th }}$ ABRA International Conference on Quality of Life Holiday Villa Langkawi, Langkawi Island, Malaysia, 15-16 Dec 2021

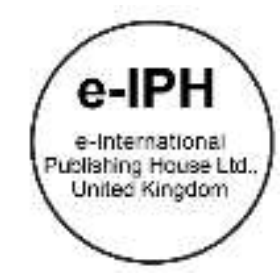

\title{
Malay Socio-Cultural Elements in Selected Malaysian Paintings of the Hashim Hassan
}

\author{
Ahmad Hakim Abdullah, Nasirin Abdillah \\ Faculty of Creative Technology and Heritage, \\ Universiti Malaysia Kelantan, Locked Bag No 1, 16300, Bachok, Kelantan, Malaysia \\ hakimabdullah08@gmail.com, nasirin@umk.edu.my \\ Tel : +601121825608
}

\begin{abstract}
This study focuses on the works of Hashim Hassan paintings. The artist is known for showcasing the essence of the Malay socio-cultural and philosophy that is in-depth within the community. This research method emphasises qualitative methods such as in-depth interviews, observations, voice recordings and data transcripts. The findings depict the philosophical and Malay socio-cultural meaning of Wau Bulan Terbang Malam (2007); the painting resonates with the classic Malay song by Tan Sri. P. Ramlee. The painting is also an inspiration for the Malay banknotes and coins, the graphic design logo of Malaysia Airlines Berhad and Wau Bulan Monuments.
\end{abstract}

Keywords: Hashim Hassan; Malaysian; Malay Socio-Cultural Elements; Paintings

eISSN 2398-4287 @ 2021. The Authors. Published for AMER ABRA cE-Bs by e-International Publishing House, Ltd., U.K. This is an open-access publication under the CC BYNC-ND license (http://creativecommons.org/licenses/by-nc-nd/4.0/). Peer-review under responsibility of AMER (Association of Malaysian Environment-Behaviour Researchers), ABRA (Association of Behavioural Researchers on Asians) and cE-Bs (Centre for Environment-Behaviour Studies), Faculty of Architecture, Planning \& Surveying, Universiti Teknologi MARA, Malaysia.

Doi: https://doi.org/10.21834/ebpj.v6i18.3061

\subsection{Introduction and Background}

Art Painting is a popular art form in the Malaysian fine art industry. In Malaysia, painters have produced their masterpieces since independence, and the art form has grown prominently in the 1960s, 1970s, 1980s, 1990s, 2000s and beyond. Over the years, local painters have presented various streams, styles and concepts across different mediums to audiences and art enthusiasts. At the same time, according to (Rahim et al., 2021), local paintings have been largely competing with artworks influenced by Western art streams such as realism, futurism, abstract expressionism, expressionism, fauvism, surrealism, cubism, pop art and dadaism.

Art painting is one of the arts that has existed for a long time, since the Palaeolithic era. Along with the advancement of production in the 21 st century towards painting, more paintings are produced. There have been many paintings in Malaysia since the post-independence era until now. Among the elements still relevant in the 21 st century are the Malay socio-cultural elements in the paintings. Among the Malay socio-cultural elements highlighted is the community culture in Malaysia. This statement is further reinforced by the opinion of one of the scholars:

Usaha pemupukan nilai budaya bangsa dalam seni catan yang mempamerkan imej sosiobudaya Melayu perlu kepada kefahaman dalam diri pelukis yang memerlukan aliran pemikiran, falsafah dan pandangan dunia dalam menyusun dan membina asas ketamadunan budaya bangsa.

(Muhammad Kamal, 2016)

This discussion shows that the production of painting is characterised by Malay socio-cultural elements that require the artist's way of thinking. The socio-culture of society influences the study of the characteristics and elements of Malay socio-culture.

\subsection{Problem Statement}

eISSN 2398-4287 @ 2021. The Authors. Published for AMER ABRA cE-Bs by e-International Publishing House, Ltd., U.K. This is an open-access publication under the CC BYNC-ND license (http://creativecommons.org/licenses/by-nc-nd/4.0/). Peer-review under responsibility of AMER (Association of Malaysian Environment-Behaviour Researchers), ABRA (Association of Behavioural Researchers on Asians) and CE-Bs (Centre for Environment-Behaviour Studies), Faculty of Architecture, Planning \& Surveying, Universiti Teknologi MARA, Malaysia.

Doi: https://doi.org/10.21834/ebpj.v6i18.3061 
Currently, the study of Malay socio-cultural aspects in the art of painting is still lacking, especially in the millennium era in the 21st century. Based on the highlights of earlier studies, there is not much detail in the context of Malay philosophy and socio-cultural in the paintings. (Muhamad Kamal, 2016). According to the statement of this problem, it is clear that in this millennium era, the study of Malay sociocultural through the art of painting is still lacking in the millennium era. Meanwhile, the lack of analysis and scholarly studies on the philosophical and Malay socio-cultural aspects is proven in the millennium era (Hassan et al., 2018). This is due to the lacking of documentation and research to unravel the philosophical and socio-cultural aspects of the Malay art of painting in the millennium era. (Sarena, 2018). Therefore, there is not much research to highlight the elements and issues related to philosophy and Malay socio-cultural to produce a critique of the art of painting in the millennium era.

\subsection{Research Aim}

This study examines the philosophy and Malay socio-cultural elements highlighted in the 21st-century paintings of Hashim Hassan, specifically Wau Bulan Terbang Malam.

\subsection{Research Objectives}

1. To identify the philosophy and Malay socio-cultural elements presented in Wau Bulan Terbang Malam painting produced by artist Hashim Hassan in 2007.

2. To investigate the value of philosophy and Malay socio-cultural elements in Wau Bulan Terbang Malam painting produced by artist Hashim Hassan in 2007.

\subsection{Research Questions}

RQ1. What are the philosophical and Malay socio-cultural elements presented in the Wau Bulan Terbang Malam painting produced by Hashim Hassan in 2007?

RQ. 2. How are the value of philosophy and Malay socio-cultural elements presented in the painting Wau Bulan Terbang Malam produced by Hashim Hassan in 2007?

\subsection{Literature Review}

\subsection{Malay Cultural Elements in the Art of Painting in the Year 1960s}

In the 1960s, the paintings have shown the Malay cultural themes development on display (Sarena, 2018). Malay socio-cultural elements became the main theme of almost all paintings in the 1960s (Ahmad Hakim et al., 2021c). Malay culture in the paintings produced this year usually highlights culture and society (Alina et al., 2015).

Surveys show that although National Cultural Congress was not established in 1971 (Mohd Firdaus Naif, 2017), painters' themes that year are quite satisfactory from the Malay cultural aspect in the 1960s.

\subsection{The Concept of Malay Cultural Ideas the Art of Painting in Malaysia in the Year 1970s}

In the 1970s, the paintings in Malaysia began to exhibit the characteristics of Malay cultural identity, which is the relationship between the issues and themes highlighted in the painting. Among the important paintings in making it a symbol of Malay culture is through the core of the delivery of meaning related to Malay culture (Khazilah \& Liza Marziana, 2018) is the painting produced in 1978 by Syed Ahmad Jamal entitled Gunung Ledang Tanjung Kupang that provides the meaning related to issues raised by painters regarding Malay cultural symbols.

Among the trendy issues discussed in Syed Ahmad Jamal's painting is the tragedy of the Malaysia Airlines System plane crash that crashed at Tanjung Kupang in 1978. This makes this painting highlight the issue and theme as an abstract art of painting through the expression of line elements contained in Syed Ahmad Jamal's painting entitled Gunung Ledang Tanjung Kupang. There are elements of Malay culture, such as square-shaped lines in Syed Ahmad Jamal's paintings.

\subsection{Theme of Malay Socio-Cultural in the Art of Painting in the 1980s}

The development of painting in the 1980s provided a more positive impact through application elements that focused on the Malay and socio-cultural aspects among prominent painters such as Ruzaika Omar Basaree, Syed Ahmad Jamal, Mastura Abdul Rahman and Sulaiman Esa (Muhammad Salehuddin \& Hairulnisak, 2021). Among the significant paintings in the 1980s in Malaysia are the Siri Dungun by Ruzaika Omar Basaree, Mahsuri by Sulaiman Esa, Langit dan Bumi by Syed Ahmad Jamal and Interior No.29 by Mastura Abdul Rahman (Wan Soliana et al., 2021)

\subsection{Malay Socio-Cultural Identity in the Art of Painting from the Year 1990 s to $1999 \mathrm{~s}$}

In the 1990s, the paintings were widely expressed among renowned painters such as Din Omar and Jalaini Abu Hassan (Ahmad Hakim et al., 2021b). The themes styled in the art of painting in the 1990s were more of Malay self-expressions. Among the outstanding paintings produced by Din Omar in the 1990s is Antara Dua Hidangan, produced in 1992. The painter emphasises the Malay socio-cultural theme, which explains how to enjoy food through traditional ways related to the socio-cultural theme of the Malay community described, such as the study subject in Din Omar's paintings (Siti Humaini, 2020). 


\subsection{Research Methodology}

This section discusses the appropriate qualitative research methods for conducting this study. Therefore, the in-depth interview, observation, voice recording and transcript data are also used to collect data. The study must be carried out systematically to ensure a comprehensive and accurate result. In this qualitative study, the researcher's role is to analyse and critique the artist's artwork based on Erwin Panofsky (1939) western theoretical art critique model, specifically the iconography analysis.

Table 1. Three Stages of Analysis Tools Based on Erwin Panofsky Iconography Analysis (1939) Art Critique Theory (Erwin Panofsky)

Pre-Iconographical Description

Iconographical Analysis

Iconological Interpretation
Identify the form of artwork, i.e., painting, drawing, print or sculpture.

- $\quad$ The basic evaluation focuses on art elements and principles such as lines, colours, appearance, repetition, diversity, emphasis, and contrast.

$>\quad$ The icon or image drawn should be identifiable by the audience in a distinct cluster. In addition, the icons or images drawn should evoke reactions and give specific meanings to the audience.

$>\quad$ Iconology refers to either explicit (direct) or implicit (indirect) meanings. The theory emphasises that the audience is the one making descriptive observations and interpretations. for example, the theme and purpose behind the title of the work, based on their respective artistic backgrounds.

(Source: Panofsky, 1939) 
Research Title:

Malay Socio-Cultural Elements in Selected Malaysian Paintings of the Hashim Hassan

Erwin Panofsky (1939) book 'Studies in Iconography: Humanistic Themes in the Art of the Renaissance' outlined three stages of iconography to evaluate a painting produced by Hashim Hassan in the New Millennium

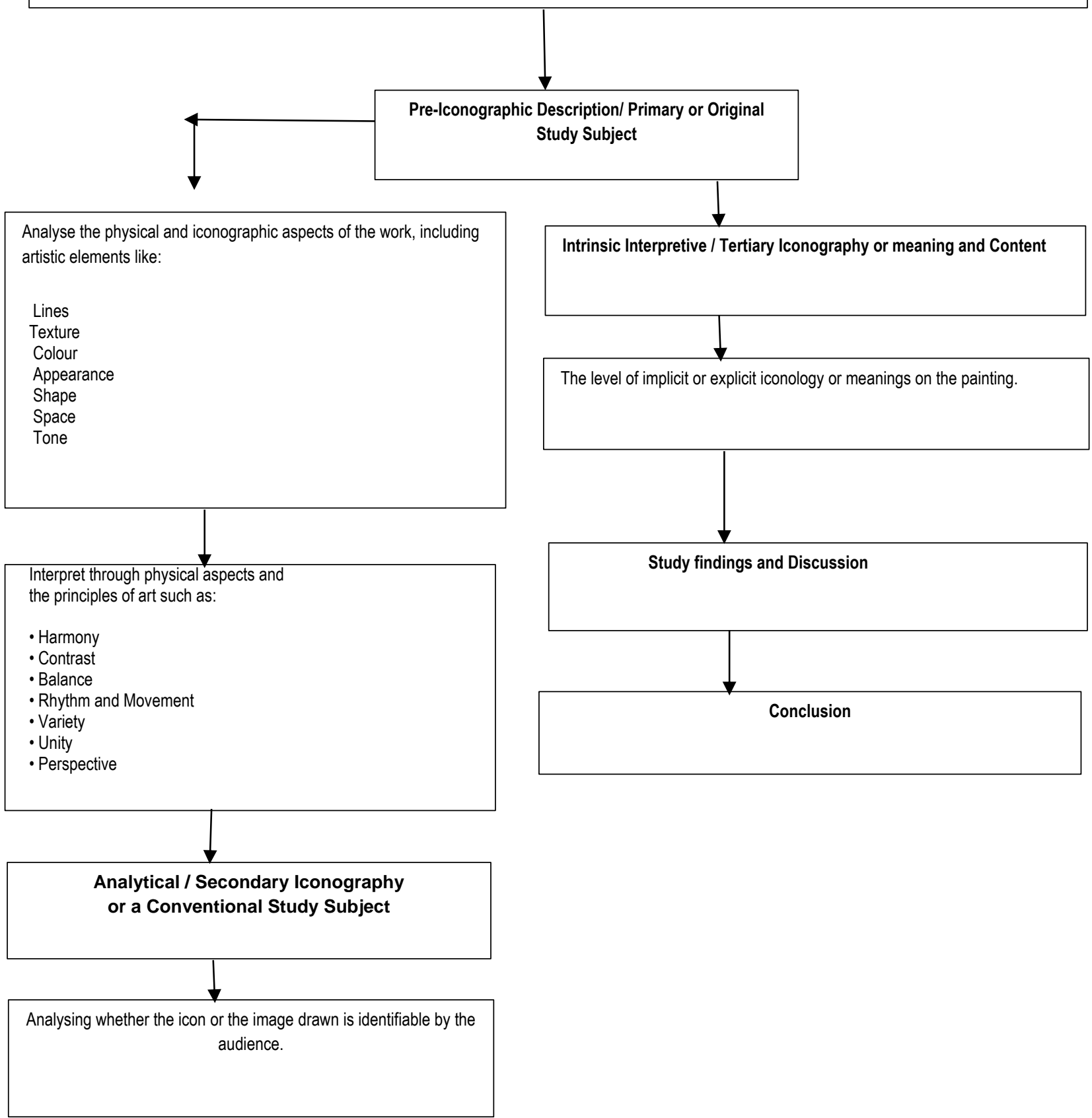

Fig. 1: Conceptual Framework 


\subsection{Findings}

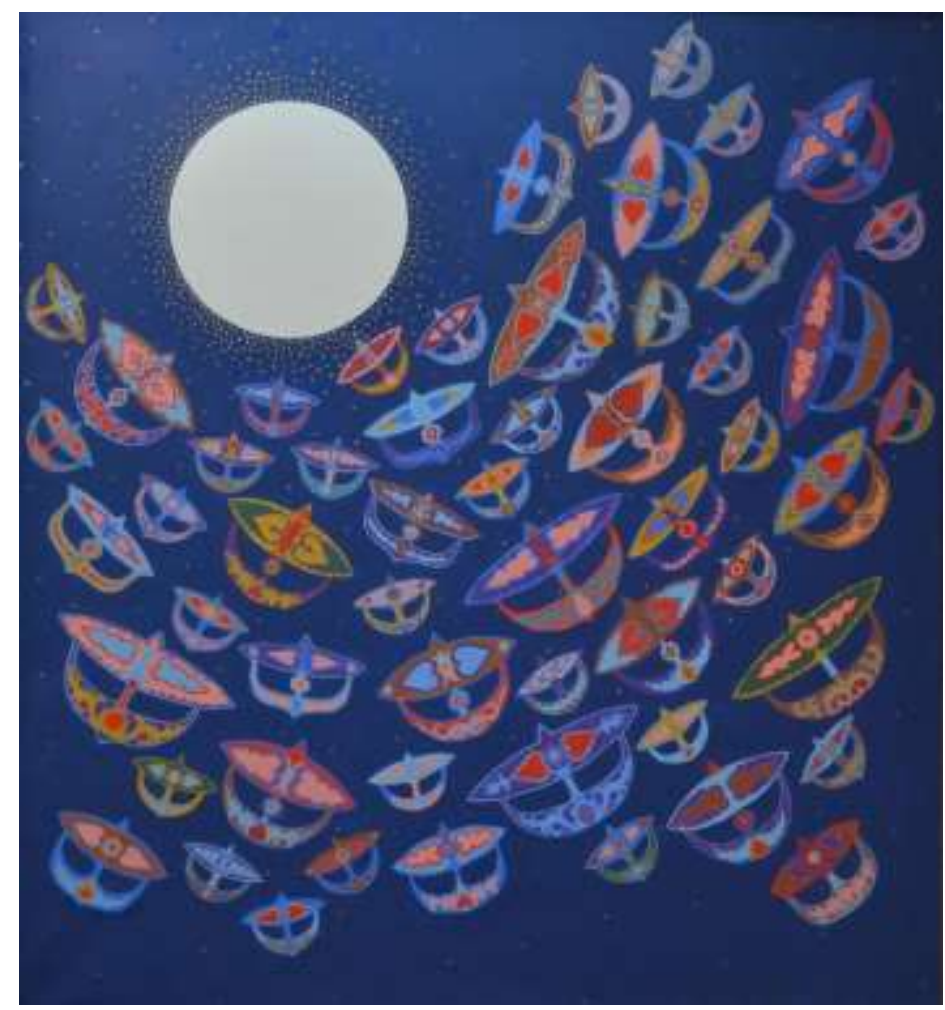

Fig. 2: Hashim Hassan. (2007). Wau Bulan Terbang Malam [140 cm x $152 \mathrm{~cm}]$. (Source: Researcher's Personal Collection)

\subsection{Pre-iconographical Description}

Wau Bulan Terbang Malam is the second work produced by Hashim. It was produced in 2007. The painting used warm and cool colours with acrylic medium on canvas. The use of colours could influence audience reactions, as described by Liza Marziana et al. (2015),

Warm and cool colours can influence the audience physically, psychologically and emotionally. Certain colours in the surroundings can influence our alertness, sense of well-being, and inner space. In addition, colours can be semiotic and, thus, associated with ideas and meanings.

(Lazzari \& Schlesier, 2008: 34)

Hashim's painting highlights fine lines in the subject matter, Wau Bulan (moon kites) presented in various scales and sizes from a formalistic perspective. This artwork gives an impression of the neatness of the design lines forming the moon kites, which used to be a pride of the Malay community. In addition, the artist used bold visual elements to emphasise the moon. The moon was also placed at the front of the painting, with the moon kites surrounding it. The artist also emphasised the shapes of the moon kites flying at night. In this regard, the colours and patterns in moon kites are mostly varied to differentiate one from another. In this painting, some of the moon kites have a similar colour as the night sky used as the background of this work. This gives the impression that each player has different preferences in decorating their kites. Hashim also highlighted a vast space with no obstructions to show the beauty of the full moon created by Allah SWT that can only be seen at night. This artist has also chosen the moon kite icon for this painting since it is closely related to the picture of the life of the Malay community who have a spirit of cooperation in playing this traditional game. This indirectly indicates that the artist appreciates the subject matter of Malay socio-cultural elements.

\subsection{Iconographical Analysis}

The subject for Hashim's Wau Bulan Terbang Malam painting in Figure 2 is 'Wau Bulan (moon kite), a traditional game played by Malay communities. Flying Wau Bulan was a popular leisure activity, particularly on the East coast, such as in Kelantan and Terengganu in the olden days where there were no digital toys like now in the modern era. Flying moon kite is popular among older men and the younger generation who showed interest and skills in flying it.

Flying Wau Bulan remains a common traditional game among the Malay communities in Kelantan and Terengganu. It has become a popular attraction to the states and is commonly played in events organised by agencies such as the Kelantan State Department of Culture and Arts (JKKN). The relevance of the kite until now is deep-rooted in the respect and appreciation to the Malay heritage demonstrated by the young and old generation in these regions.

\subsection{Iconographical Interpretation}




\section{Emalaysiag}

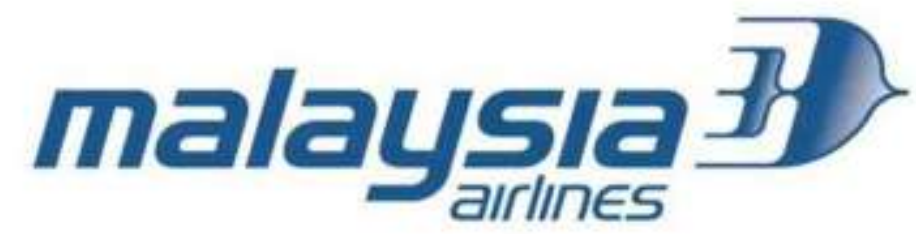

Fig.3: The red and blue Wau Bulan symbol at the top was used by Malaysia Airlines (MAS) before the company underwent a new branding exercise. The mixed red and blue colour of the Wau Bulan graphic logo was changed to fully blue, as shown at the bottom.

(Source: https://www.campaignasia.com/article/malaysia-airlines-quietly-launches-new-logol $\underline{297124)}$

Wau Bulan is a symbol often used as a non-verbal communication medium to convey explicit and implicit messages. The moon kite symbol is featured in the company logo of Malaysia's national carrier, Malaysia Airlines Berhad (MAB) (Figure 3). The symbol is similar to the kites in Hisham's painting. According to Hashim, the shapes of the moon and the Wau Bulan have a deep meaning and are interconnected. Its use on the MAB or Malaysia Airlines logo represents the legacy of the Malay philosophy identity. It creates a strong sense of identity and pride in the hearts of Malaysian citizens, especially the Malays on board the company's plane. The new version of the logo was created to create a stronger positive impression towards the airline, which has been operating for more than 49 years and flying to more than 64 destinations worldwide.

In addition, the philosophy and significance of the moon kite for the Malay community in Kelantan are also highlighted through performing arts, specifically the Dikir Barat, which is usually performed by the Remang Malay Royal family in the southern region of Thailand. The Wau Bulan Dikir Barat is still widely performed by local singers like Halim Yazid, Fadil Turbo and Jemy Intan Berlian. The dikir barat is usually performed along with dikir barat group from East coast, like Gerbang Ranjuna (Figure 4). The lyrics of the song Wau Bulan sung by the original singer, Seman Mamat, which was performed during the Makmur Gold Tunjung opening ceremony, are shown below.

Eh wau bule, Eh wau bule

Wau bule, teraju tigo

Eh wau bule, Eh wau bule

Wau bule, teraju tigo.

Ini male samo-samo

Samo-samo bersuko rio

Ini male samo-samo

Samo-samo bersuko rio.

(Santai Studio,2019)

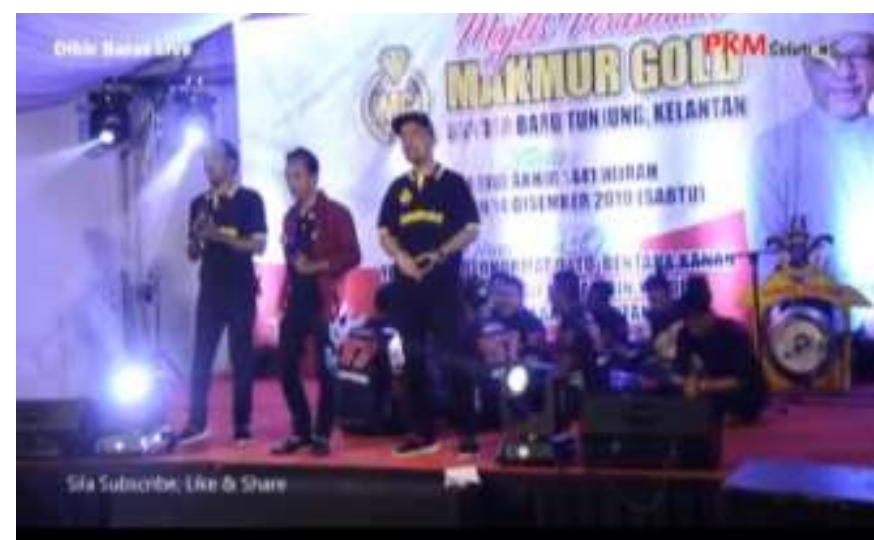

Fig.4: Video clip of the song Wau Bulan sung by Halim Yazid, Fadil Turbo, Jemy Intan Berlian dan Gerbang Ranjuna.

(Source: PKM Solutions, 2019) 
The lyrics of dikir barat in Kelantan convey a good meaning and messages that reflect Malay cultural heritage's richness. The lyrics mostly highlight political, social, heritage, traditions and religious values (Ahmad Hakim et al., 2021a). Conveying messages through dikir barat performance allows listeners to enjoy and appreciate lyrics loaded with noble values and philosophy about the moon kite. The appreciation of the unique philosophy of the Wau Bulan has inspired several organisations such as Bank Negara Malaysia (BNM) to use Wau Bulan as a motif on the 50 cent coins and RM1 banknotes since 1989. In addition, Hisham had incorporated the Malay socio-cultural and philosophy of the Wau Bulan as represented in paintings in his artwork. This can also be linked to the meaning conveyed in the lyrics of Engkau Laksana Bulan, a song by legendary composer Tan Sri P. Ramlee.

Meanwhile, the RM1 banknotes and 50 cent coins have been used in transactions in Malaysia for a long time. The Wau Bulan symbol on the banknotes and coins represents the effort to increase Malaysian's love for the country. It also reflects the undying legacy of the Malay civilisation. Furthermore, inspired by Hashim's work, Malaysia Airlines has used Wau Bulan and Batik in its Fly Malaysia campaign to attract more tourists to Malaysia. The use of a Wau Bulan logo with a batik pattern represents the pride of Malaysian tradition and culture. The design elements of Batik motifs heavily feature leaves and local floras such as plumeria, jasmine, and hibiscus.

The Malay socio-cultural values with the philosophy of Malay symbolism are evident in the design of the Malaysian currency notes. It also highly features the hibiscus, the national flower of Malaysia, representing patriotic values. The five flower petals symbolise the five principles of Rukun Negara, namely belief in God; loyalty to King and country; the supremacy of the Constitution; the rule of law as well as decency and morality. These five principles form the fundamental of Malay patriotism and should be memorised and practised by all Malaysians. Meanwhile, in Wau Bulan Terbang Malam (Figure 2), Hashim has conveyed and emphasised the positive values in Malay society (Baharuddin, 2011). The use of a full moon as a subject in his painting could be linked to the Malay community who highly regard the greatness of Allah SWT and His creations. In the meantime, Wau Bulan represents the traditional Malay sport commonly played in Kelantan, Perlis, Kedah and Terengganu (Sarena, 2010). In general, Hashim is very appreciative and careful in presenting his ideas and subjects. In Wau Bulan Terbang Malam, he has used the symbolism of Malay philosophy to convey messages related to current issues in the context of art communication.
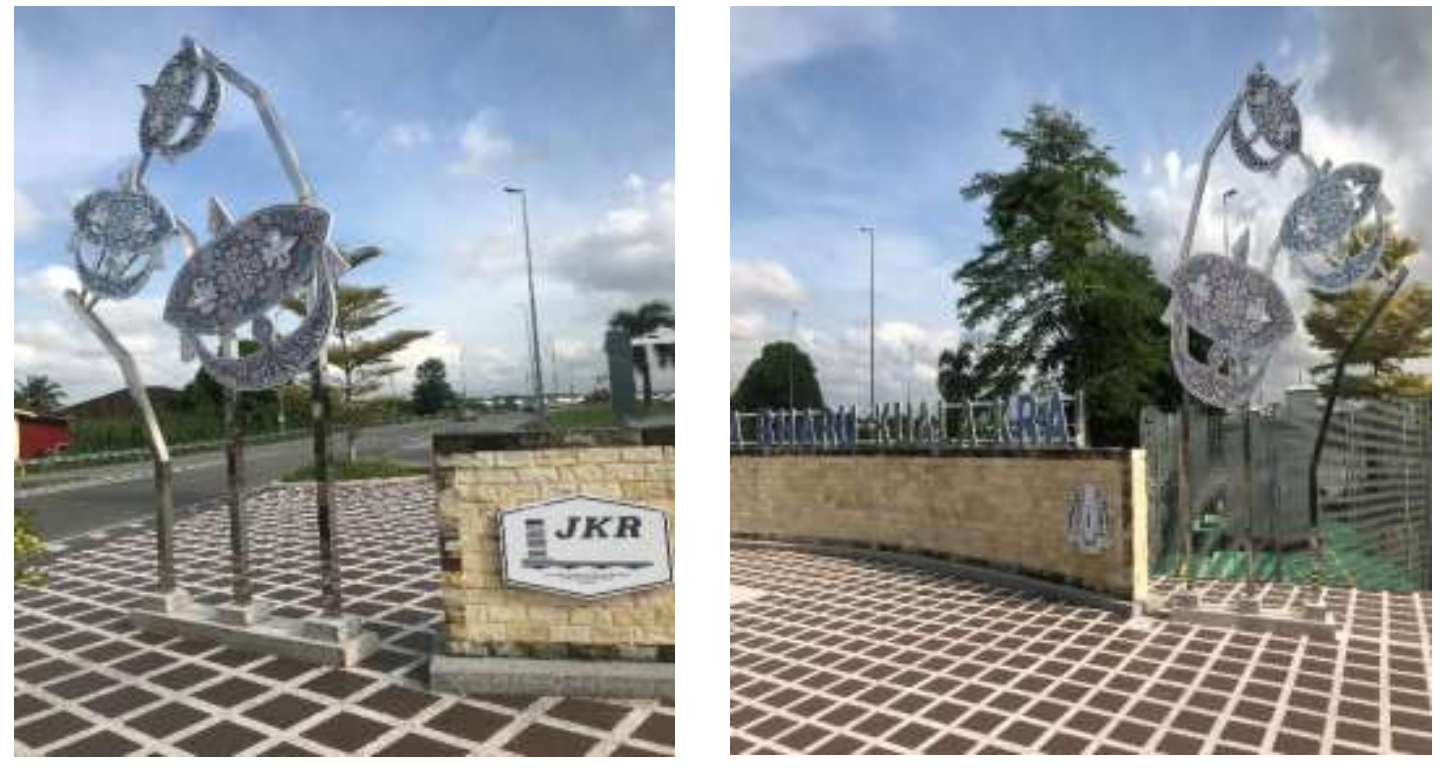

Fig.5: Wau Bulan Monument

(Source: Researcher's Collection, 2021)

The above photos show a monument found beside Pasir Hor road, Kota Bharu, Kelantan. This monument also depicts the subject matter of Wau Bulan (Figure 5), which was inspired by this artist as a cultural material used to inspire ideas in Hashim Hassan's paintings.

\subsection{Discussion}

Hashim's Wau Bulan Terbang Malam features examples that we could follow regarding the noble philosophical values and positive Malay symbolism it represents. In 2007, the painting by Hashim began to demonstrate the style of surrealism. Hashim has successfully conveyed the content of Malay philosophy and socio-culture in the painting entitled Wau Bulan Terbang Malam. Based on this study's discussion, this has proven that Hashim is an artist who applies the subject matter of the moon in the context of Malay philosophy and socio-culture. This is due since the moon kite is an important icon in this artist's work. In addition, the philosophical aspect can be seen with the existence of traditional Malay songs sung by Tan. Sri P. Ramlee gives a philosophical meaning related to the rhythm of Malay songs that are melodious with this singer's voice. Furthermore, the philosophical aspect of the Wau bulan icon also reflects the socio- 
cultural value of the Malays, namely the spirit of cooperation among the Malay community on the east coast, which is important to ensure unity and harmony of life.

\subsection{Conclusion and Recommendations}

In conclusion, Hashim Hassan's paintings have positively impacted visual art, especially the local arts in the 21st century. Hashim used a contemporary style that suits the current generation's tastes and aligns with the modernity trends among Malaysian painters. This study only includes one work produced in 2007, namely Hashim Hassan's painting entitled Wau Bulan Terbang Malam. This study looked at the style of surrealism with subject matter characterised by tradition that includes Malay philosophy and socio-cultural. Through the painting, Wau Bulan Terbang Malam can be maintained as the identity of painting art in Malaysia in Malay philosophy and socioculture. Meanwhile, it is hoped that young artists and art trainees can also maintain the subject matter with the concept of Malay philosophy and socio-culture so that the art of painting in the 21 st century can be maintained as a national identity and known in Malaysia and worldwide. In addition, it is hoped that the government and non -governmental organisations (NGOs) will work together and play a role in encouraging young artists to produce paintings featuring Malay philosophy and socio-culture in the future in line with the manifestations of the 1971 National Cultural Congress. This is to ensure that the artist can produce the development of painting according to the latest circulation related to the production of painting but still does not ignore the philosophical and socio-cultural characteristics of the Malay as a national identity. Apart from that, the management of the galleries and museums also needs to provide space and opportunities for young artists to produce themed paintings related to aspects of Malay philosophy and socio-culture in the 21 st century.

\section{Acknowledgements}

The researchers would like to thank and appreciate the Publication and Rating Division by the Research and Innovation Management Center (RMIC), Universiti Malaysia Kelantan, for this publication incentive. The highest appreciation and thanks to the Ministry of Higher Education Malaysia (KPT) and the Ministry of Education Malaysia (KPM) for providing funds and financial sponsorship during this Postgraduate study.

\section{References}

Abdullah.S. (2018). Malaysian Art Since the 1990s: Postmodern Situation. Dewan Bahasa dan Pustaka: Kuala Lumpur.

Ali, J. (1993). Kesenian Melayu dari Perspektif Sosiologi-Budaya. Ceramah Terbuka Rupa dan Jiwa: Kesinambungan Tradisi Dalam Seni Rupa Sezaman.

Aziz, M. K.A. (2016). Kritikan Seni dari Perspektif Sosio Budaya di Malaysia, Tesis Doktor ljazah Falsafah, Universiti Malaya. http://studentsrepo.um.edu.my/id/eprint/6733. Abdullah, S. (2010). Absenteeism art Malaysia Identity in Art in the early years of independence. JATI-Journal of Southeast Asian Studies, 15, 133-150

Abdullah, S. (2012). Art criticism versus art writing: the Malaysian situation. KEMANUSIAAN, 19(2), 63-78.

Abdullah, A.H., Ibrahim, Y., \& Badaruddin, M.I. (2021a). Malay and Islamic Traditions Elements Through the Paintings Of Mastura Abdul Rahman, Ruzaika Omar Basaree and Haron Mokhtar, International Journal Of Heritage, Art And Multimedia., 4(12), 01-16.

Abdullah, A.H., Ibrahim, Y., Halid, R.I.R. (2021b). Analisis Intrinsik Simbol Budaya Melayu dalam Karya Catan Moden Terpilih Jalaini Abu Hassan dan Fatimah Chik, International Journal of Creative Future and Heritage (TENIAT), 9 (1), 52-68.

Abdullah, A.H., Abdillah, N.(2021c). Heritage Value of the Malayness Socio-Cultural Symbols in Millennium Artist Series of Arts: A Research Analysis in Semiotics, Journal of Educational and Social Research, 11 (4), 260.

Abdullah, A., Razais, N.I., \& Silah, S. (2015). Symmetry in Analysis Paintings: A Compositional Analysis. International Colloquium of Art and Design Education Research (i-CADER 2014) (pp.603-611), Springer, Singapore.

Ali, Z. (1979). Art and identity. The Contemporary Masa Kini, Journal of Art and Literature, 1(2), 5-12.

Ali, Z. (1993). Rupa dan Jiwa: Ceramah Terbuka di Balai Seni Negara. Kuala Lumpur, Malaysia.

Baharuddin, S. A. (2011). A History of An Identity of a History; An Identity of History the Idea and Practice of "Malayness" In Malaysia Reconsidered. Journal Of Southeast Asian Studies, 32(3), 355-366.

Hassan, N. A., Amin, P., \& Tohid, M. S. (2018). Identification of Malay Aesthetic Concept in Visual Artworks. In Proceedings of the Art and Design International Conference (AnDIC 2016) (pp. 375-382). Springer, Singapore. 
Humaini, S., Ahmad, S., \& Ahmad, S. (2020). Elemen budaya dalam karya seni catan Malaysia: satu tinjauan. Idealoggy, 5(1), $157-164$.

Idris, N., \& Noh, L. M. M. (2018). A Critical Analysis of Malay Symbolism in Datuk Syed Ahmad Jamal Artwork: Gunung Ledang, 1978. International Journal of Academic Research Bussiness in Progressive Education \& Development 7(4), 63-72. Doi: 10.6007/IJARBSS/v8-i10/4708.

Lazzare, M \& Schleisier. (2008). Exploring Art: Global, Thematic Approach, 3 rd. Edition. USA. Thomas Learning, Inc.

Mitchell, W.J.T. (1987). Iconography: Image, Text, Ideology. The University of Chicago Press.

Noh, L., Haron, H., Samian, A., \& Hasan, A. (2015). Formalistic as an Analysis Method in Signifying the Malay Cultural Symbol in Malaysian Modern Art of Paintings. Mediterranean Journal of Social Sciences, 6(4), 30. Retrieved from https://www.mcser.org/journal/index.php/mjss/article/view/7048

Panofsky, E. (1939). Studies in Iconography: Humanistic Themes in the Art of the Renaissance (1st ed.). Routledge.

Rahim, R. A., Mokhtar, M., Vermol, V. V., \& Legino, R. (2021). Iconography Underpinning Malaysian Portrait Painting. Environment-Behaviour Proceedings Journal, 6(SI5), 119-124.

Soliana, W. M. Z. W., Marzuki, I., Rushana, S., \& Hafiza, G. N. (2021, July). The symmetry analysis in Sulaiman Esa paintings through Islamic art concept. In AIP Conference Proceedings (Vol. 2347, No. 1, p. 020133). AIP Publishing LLC.

Zakaria, M.S.B., Merman, H.B. (2021). Exploring the Malayness of Mastura Abdul Rahman's painting, International Journal of Art and Design, 4(6), 47-55.

Zailuddin, M. F.N.O. (2017). Interpretasi Karya Seni Visual Terpilih Bakat Muda Sezaman (2000-2013) Dari Konteks Dasar Kebudayaan Kebangsaan. Tesis Sarjana. Universiti Sains Malaysia. 